\title{
The Ethical Self in the Later Foucault: the Question of Normativity
}

\author{
Gavin Rae ${ }^{1}$
}

Accepted: 23 November 2021

(c) The Author(s) 2022

\begin{abstract}
Michel's Foucault's later work has been the subject of much critical interest regarding the question of whether it provides a normative stance that prescribes how the self ought to act. Having first outlined the nature of the debate, I engage with Foucault's comparative analysis of the ethical systems of ancient Greeks and Christianity to show that he holds that the former maintains that the ethical subject was premised not on adherence to a priori rules as in Christianity, but from and around an on-going process of practical experimentation. From this, Foucault goes on to describe the practices through which the self acted to make and re-make itself, which leads to the question of whether such descriptions also contain prescriptions as to how the self should act. I argue that they do contain a prescriptively normative stance, but in a very specific sense. Rather than delineating the specific ethical commitments we should adopt, Foucault takes off from the example of the ancient Greeks to insist that individuals should adopt an indeterminate orientating principle based on absolute openness to each context, with this principle given content through a context-specific, spontaneous, on-going, and inherently individual, albeit socially situated, process of practical experimentation. The result is a highly original account of normativity that makes individuals absolutely responsible for themselves and their ethical activities in each moment.
\end{abstract}

Keywords Foucault $\cdot$ Normativity $\cdot$ Ethics $\cdot$ Self

It has been noted that 'normativity' has, at least, two different but ultimately related senses, insofar as it (1) can describe the norms that govern a way of life, and/or (2) prescribe how subjects ought to act (Butler, 1999: pp. xxi-xxii; Kelley, 2018: p. 2). Michel Foucault deals with the former predominantly in his archaeological and genealogical writings in order to undermine 'the founding function of the subject'

Gavin Rae

gavinrae@ucm.es

1 Department of Logic and Theoretical Philosophy, Universidad Complutense de Madrid, Madrid, Spain 
(2010a: p. 12) and to rethink the subject as an effect of power relations. Although a number of commentators have concluded that the subsequent notion of a constituted subject undermines the possibility of agency (Dews, 1989; McNay, 1992), others have argued that this critique conflates 'effect' with 'determine.' As such, Foucault's claim that the subject is an effect of power relations is needlessly understood by his critics to mean that the subject is determined by them, when it more accurately simply means that it is 'conditioned' by them (Allen, 2008; Bevir, 1999; Rozmarin, 2005; Rae, 2020). Whereas a deterministic reading negates the possibility of individual agency, a conditioned reading permits and, indeed, demands that the subject act to bring about the norms that condition it. It is at this juncture that the question of Foucault's later works-from 1980 until his death in 1984-comes to the fore. Whereas proponents of the determined reading struggle to see how his later orientation accords with his former genealogical work on power and so conclude that it points to a fundamental rupture within his oeuvre, those affirming the conditioned reading insist on a complementary relation wherein Foucault's later works engage with the ways in which the conditioned self ${ }^{1}$-outlined in his earlier genealogical writings - contributes to its own formation.

Taking off from this conditioned reading, this paper $^{2}$ is guided by the contention that Foucault's late comparative discussion of the ethical systems of the ancient Greeks and Christianity aims to achieve, at least, three ends: First, it tries to show that the ancient Greeks maintained that the ethical subject was premised not on adherence to a priori rules as in Christianity, but was conditioned from and around specific conducts and practices that were both individual and contextual. ${ }^{3}$ Second, I argue that Foucault affirms a contextual, practice-based ethics that complements his previous focus on the 'techniques of production, techniques of signification or communication, and techniques of domination' (2000e: p. 177) with an emphasis on, what he calls, the "technologies of the self" (2000e: p. 177) that describe the practices through which the self acts to make and re-make itself. Finally, I argue that Foucault's later work points to a very particular conception of normativity, by which I mean the prescriptive sense of the term that identifies how individuals should act. Instead of simply affirming the adoption of a priori ethical rules or norms to predetermine ethical action, Foucault takes off from the lessons learnt from his analysis

\footnotetext{
${ }^{1}$ Having decentred the subject from its foundational role, Foucault's attempt to describe the agency of this decentred subject leads him from the subject to the self. The reason for this change is both linguistic, insofar as he notes that the word 'the self' is not found in French, which is unfortunate 'because ... it's a good word' (2016b: p. 116), and conceptual, insofar as it allows him to distinguish his position from the foundationalism of 'the philosophy of the subject' (2016a: p. 21), all the while denoting 'the kind of relation that the human being as a subject can have and entertain with himself' (2016b: p. 116).

${ }^{2}$ I would like to acknowledge and thank the editors and reviewers for their helpful comments on an earlier version. This article forms part of the activities for the following research projects: (1) 'Agency and Society: An Inquiry through Poststructuralism' (PR108/20-26); (2) 'Differential Ontology and the Politics of Reason,' funded by the Government of the Region of Madrid, as part of line 3 of the multiyear agreement with the Universidad Complutense de Madrid: V PRICIT Excellence Program for University Professors (Fifth Regional Plan for Scientific Investigation and Technological Innovation); and (3) 'The Politics of Reason' (PID2020-117386GA-I00), financed by the Ministry of Science and Innovation, Government of Spain.

3 Evaluating the validity of Foucault's descriptions or conclusions regarding these systems is (purposefully) out-with the boundaries of this article. I work within the confines of Foucault's thinking to clarify the form of normativity guiding it.
} 
of the ancient Greeks to assert the adoption of a general orientating principle to guide individual activity, but leaves it up to individuals to determine how this will be played out in terms of specific determinations in each context. Instead of falling back on a pre-established framework that determines what an individual's ethical commitments should be regardless of context, the idea is to fully contextualize the generation of those commitments so that individuals need to constantly re-actualize them based on the specifics of each context. Only this will, on Foucault's telling, genuinely realize individual freedom while also making individuals fully responsible for themselves and their actions.

To outline this, I face an issue that all commentators on Foucault's later works must confront: the sheer volume of texts composing the period 1980-1984, many of which are seminars given internationally, lectures at the Collège de France, and short interviews. Rather than being able to focus on one text to outline the 'later' Foucault or holding that one text is the keystone to unlocking the others, significant hermeneutical work is necessary to bring these texts together coherently. For this reason, while I am aware that their heterogeneity might permit alternative readings, I am guided by the contention that the argument proposed is at least possible from his later works, an interpretation backed up by significant textual support. With this, I piece together my argument from a variety of Foucault's later texts to defend a position that depends upon but is distinct from other readings found in the secondary literature. However, because, at times, I use concepts that are, strictly speaking, not found in Foucault's own terminology—although they tend to have a long history in the secondary literature and I will argue are both implicit to Foucault's thinking and/ or bring out its originality ${ }^{4}$-it will be helpful to first outline the nature of the debate to which I am responding, clarify a number of the terms that I will use, and provide a schematic outline of my argument, before going on to show how that argument plays out throughout Foucault's later works.

\section{The Normativity of Foucault's Ethical Self}

The claim that Foucault's later work is prescriptively normative is a controversial one because a long-standing criticism of his thinking is that it offers no logically consistent form of normativity to direct or justify individual action. For example, Charles Taylor claims that there is not and cannot be any justified normative stance given that there is no ahistoric foundation from which to ground it and judge the validity of competing claims (1985: pp. 177-184); Jürgen Habermas concludes that Foucault's thought falls into contradiction because he cannot justify his own critical stance (1987: p. 279); and Nancy Fraser claims that Foucault's work implicitly

\footnotetext{
${ }^{4}$ I would also add that the use of concepts 'alien' to a system of thought is a practice that Foucault himself utilizes, most (in)famously when he employs concepts such as 'self' and 'subject' to engage with the Ancient Greeks, despite those concepts (depending upon issues of translation) either not being part of their conceptual schema or having a very different meaning to how they have been understood in much post-Cartesian and/or contemporary thought.
} 
utilizes and depends upon a form of normativity - his inquiries reveal how we should engage with questions of power, sexuality, mental illness, and so on-that the afoundationalism inherent in his conception of power relations disqualifies (1989a: pp. 27-33, see also 1989b: p. 50). ${ }^{5}$ Although these commentators criticize the (lack of) normativity in Foucault's (later) works, Mark Kelley (2018: p. 18) comes to a similar conclusion-that Foucault's thinking is non-normative, insofar as it does not affirm a particular norm to structure political action-but insists, contra Taylor, Habermas, and Fraser, that this is a positive occurrence that permits a radically distinct form of politics.

Alternatively, however, a number of commentators have argued that Foucault does purposefully depend upon and, indeed, affirm a normative stance. These positions run across two, ultimately related, axes. The first questions whether Foucault's normative stance is theoretically or practically grounded. In the former, a norm is prefigured to guide action; in the latter, action or practice generates the norm. There is general consensus that Foucault affirms the latter. Verena Erlenbusch-Anderson (2018: p. 182), for example, distinguishes between rule-bound and practice-based forms of normativity to claim that, contrary to mainstream political theory, Foucault affirms the latter over the former, while Beatrice Han-Pile maintains that Foucault's normative prescription is not based on or justified by an 'external justification [but] through the exercise of critique as a performative practice of the self' (2016: p. 86). However, neither she nor Erlenbusch-Anderson indicate what norm guides practice to show how Foucault thinks that the self should act or how the norm emanates from practice. It is therefore unclear what they take to be the normative-which it will be remembered is understood to entail precisely this prescription-moment in Foucault's (practice-based) account.

The second axis agrees that Foucault's normative stance is practice-based, but is divided on whether the practice aims to undercover a norm that is universizable; that is, whether it aims to establish a single norm valid for all contexts and selves. Colin Koopman, for example, suggests that Foucault's normative stance is orientated towards 'universalizability' (2013: p. 262), albeit in a 'contingent' (2013: p. 262) rather than a priori or ahistoric form. In other words, the norm proposed is valid depending on the extent to which it is understood to work in different situations with the judgement about 'what works' being determined by whether it is judged to be universizable: 'Norms need be both bound to their contexts and capable of transcending those contexts. Anything that works must work here and now and also be capable of working somewhere else too' (2013: p. 262). Similarly, Sacha Golob claims that Foucault's normativity is premised on a certain sense of pragmatism wherein the idea of a universal norm is replaced with a Deweyean process of potential universalization, one in which we progressively apply something, be it an ethical standard or a scientific unit of measurement, to an increasing range of first order cases and continue to do so insofar as that proves fruitful-by our own ever changing lights' (2015: pp. 685-686). For

\footnotetext{
5 Paul Patton also claims that normativity is only 'implicit' (2016: p. 228) to Foucault's thinking, but, in distinction to Fraser, does not criticize this.
} 
Golob, Foucault's conception of normativity is (1) underpinned by and orientated towards a potentially universal standard that is (2) derived from and justified by contextually based, subjectively determined pragmatic judgement.

In contrast to Koopman's and Golob's universalist position, Amy Allen argues that Foucault affirms not a process of universalization, but what she calls 'principle contextualism' (2014: p. 55), in which Foucault affirms adherence 'to normative principles that are universal in scope' (2014: p. 55), but that are not grounded in 'the meta-normative claim that those principles are grounded in a contexttranscendent perspective that blots out space and time' (2014: p. 55). For Allen, then, Foucault does affirm a particular principle that guides how all individuals should act-for this reason, there is normativity and universality in his thinking-but she rejects the notion that what this principle means is prefigured for all contexts and times or that it aims for such status. Allen does not, however, go on to describe what the principle motivating Foucault's normative stance is.

My intervention sides with those who claim that Foucault's thinking does offer a normative prescription about how the self should act, but argues that to understand it we need to combine aspects of a number of the analyses found in the secondary literature and, indeed, introduce a number of subtle conceptual distinctions. First, I distinguish between normativity based on a priori rules which are fixed and determining for how we must act in all situations, and normativity based on principle(s) that describe (a) general norm(s) that guide(s), without determining, action. An example of the former would be that an individual should never intentionally kill any living being. It sets out a rule that determines, regardless of the situation, how to act. The latter would be, for example, to affirm 'justice' or 'freedom' as the principle to guide action without determining the specific actions that either entails or requires. I understand that Foucault's normative stance is of the latter kind, but argue that rather than affirm a positive norm (justice, freedom, law, good, etc.), he empties this principle of all determining factors. For this reason, his normative stance is best described as affirming the absence of any foreclosing of actions through the adoption of a priori conceptions of right or wrong. I call it 'normative open-ness.'

Second, it is necessary to clarify the level at which Foucault pitches his normative principle. To do so, it is helpful to follow Koopman's distinction between normative 'orientations' (2013: p. 189), which describe the 'structural background, or formal conditions ... of possibility of ethical response in the present' (2013: p. 189), and normative 'commitments (or contents, theses, positions, strategies, techniques, equipment, rules, and concepts) offered by an ethics [which] specify the conditioned practical matters of an ethics thus oriented' (2013: p. 189). A normative orientation points to the 'background,' or 'pre-reflective' stance that structures ethical commitments and action; it orientates without providing specific content as to how to act. Such content is provided by the individual's (reflective) normative commitments that determine the specific actions necessary to act ethically and to fulfil one's orientation. Whereas there is a tendency to pitch prescriptive normativity at the level of commitments, I argue that Foucault's innovation is to argue that normativity should be and is pitched at the level of orientation. He therefore prescribes the ethical orientation that should be adopted, without prescribing the commitments that must be 
engaged with to realize or actualize it. These are left up to each individual to spontaneously work out for themselves through an on-going process of contextual, practical experimentation.

Third, it is necessary to determine whether Foucault intends the normative orientation to be universal, insofar as it is a common stance for all, or particular and therefore specific to each individual. I argue that Foucault affirms a universal normative orientation, insofar as he proposes one particular ethical orientation that should motivate all ethical selves. As noted, I call this 'normative open-ness,' by which I mean that Foucault does not foreclose ethical action/commitments within predefined a priori boundaries or structures. Put positively, Foucault argues that the ethical self should always remain open regarding different activities and actions, rather than prejudging and foreclosing their ethical worth. Only this will allow each to respond to the contingencies of each context instead of reducing each context to a prefigured schema.

Finally, this brings forth the issue of how this universal normative orientation should be turned into ethical commitments. Two options present themselves: either there is a fixed, transcendent, ahistoric rule to be followed to ensure that the commitment realizes the orientation; or the realization of the orientation is open, contextual, individual, and practice-based. I argue that Foucault affirms the later, with the consequence that, while he affirms a universal normative ethical stance to orientate the ethical self, he insists that this orientation is fundamentally empty and gains content through individual action. There is, however, no a priori guide regarding the type of action to be adopted; this is determined by individuals experimenting with different activities, styles of life, and actions to determine what works or is appropriate in that moment, a judgement that is an inherently social activity.

Putting all this together reveals that Foucault's later work on the ethical self is normative because it prescribes how the self should act, but it is normative at the level of the ethical orientation guiding an individual's ethical action. This normative orientation is universal, insofar as it affirms a single principle to guide all selves regardless of context, but, crucially, it is an empty and indeterminate orientating principle that guides, without determining, an individual's actual ethical commitments and actions. The normative orientating principle is given content and, by extension, an individual's ethical commitments are revealed, from and through a spontaneous and on-going practical process of experimentation specific to each situation. Instead of such action being pre-determined/able or reduced/able to a universal commitment, the indeterminacy of the orientating principle, in combination with the specificity of each context, permits and even demands that individuals spontaneously create responses specific to each context; a process that also involves continuous, innovative individual self-creation. The question now arises as to how this schema plays out throughout Foucault's later works. 


\section{From the Constituted Subject to the Constituting Self}

In 1980, Foucault gave two lectures at Dartmouth College where he clarified his earlier thinking and in so doing started to outline a new line of research orientated from and around the question of the relationship between subjectivity and truth that would occupy him for the remaining years of his life. He starts by reaffirming his opposition to 'the philosophy of the subject' (2016a: p. 21) that dominated European philosophy after the Second World War and which 'set as its task par excellence the foundation of all knowledge and the principle of all signification as stemming from the meaningful subject' (2016a: p. 21). He is taking aim at Husserlian phenomenology and Sartrean existentialism, but he links both to Descartes to reveal that his critique is orientated against the logic governing modern philosophy.

These critical comments open a space from and through which to rethink the nature of subjectivity. In the 1981 lecture 'Sexuality and Solitude,' he follows Jürgen Habermas's insistence that subjectivity is conditioned by

three major types of technique: the techniques that permit one to produce, to transform, to manipulate things; the techniques that permit one to use sign systems; and finally, the techniques that permit one to determine the conduct of individuals, to impose certain ends or objectives. That is to say, techniques of production, techniques of signification or communication, and techniques of domination (2000e: p. 177).

However, Foucault notes that

there is another type of technique ... that permit[s] individuals to effect, by their own means, a certain number of operations on their own bodies, their own souls, their own thoughts, their own conduct, and this in a manner so as to transform themselves, modify themselves, and to attain a certain state of perfection, happiness, purity, supernatural power. Let us call these techniques "technologies of the self" (2000e: p. 177).

It is not then sufficient to simply study the techniques of domination, wherein the subject is effected by those power structures and relations, 'one must [also] take into consideration ... techniques of the self' (2000e:: p. 177) to examine 'those forms of understanding which the subject creates about himself' (2016a: p. 25).

Foucault chooses 'sexuality' as the medium through which to explore the different practices in which the self constitutes itself because

[s]exuality is part of our behaviour. It's part of our world freedom. Sexuality is something that we ourselves create-it is our own creation, and much more than the discovery of a secret side to our desire. We have to understand that with our desires, through our desires, go new forms of relationships, new forms of love, new forms of creation. Sex is not a fatality; it's a possibility for creative life (2000d: p. 163). 
Sexuality is not, on Foucault's telling, an urge or desire, but a form of selfcreation and expression. To study it is to analyse how we create and express ourselves; an analysis that reveals how the self is created through social practices. But Foucault goes on to explain that 'the problem is not to discover in oneself the truth of one's sex, but, rather, to use one's sexuality henceforth to arrive at a multiplicity of relationships' (2000b: p. 135). This does not mean that he simply advocates that we take on as many sexual partners as we can, but that we examine our sexual practices to open them to multiple forms to explore as full a variety of them as we are comfortable doing.

Just before his death in 1984, Foucault admitted that he had not got very far in outlining the ways in which this (can) occur(s) (2000f: p. 294), but he clarifies that his study of ancient (Greek) forms of sexual techniques and practices does not simply aim to describe historical sexual practices; it has philosophical and political importance, insofar as it identifies different (sexual) practices to those which govern the contemporary world to reveal that options other than those currently dominant are possible. Specifically, what Foucault finds fascinating about the ancient Greeks is that the technique governing their lives was so very different to the ahistoric rule-based ethic of Christianity that he thinks still implicitly dominates Western moral systems. In contrast, the Greeks practiced an 'arts of existence' (1985a: p. 10) wherein 'men not only set themselves rules of conduct, but also s[ought] to transform themselves, to change themselves in their singular being, and to make their life into an oeuvre that carries certain aesthetic values and meets certain stylistic criteria' (1985a: pp. 10-11). According to Foucault, the Greeks shaped their practices from and around 'a precept: epimeleisthai sautou, "to take care of yourself," to take "care of the self," "to be concerned, to take care of yourself"' (2000g: p. 226). The notion of care of the self "was the mode in which individual freedom-or civic liberty, up to a point-was reflected [se réfléchie] as an ethics' (2000f: p. 284) that depended upon and fed into a whole system of knowledge, practices, and values. It was a holistic system within which the individual had specific obligations to himself and others. This notion has largely been ignored in the history of Greek thought as the Delphic imperative " "know thyself"' (2000g: p. 226) has been privileged, but the Delphic imperative is dependent upon the prior care of self: 'In Greek and Roman texts, the injunction of having to know oneself was always associated with the other principle of the care of the self, and it was that need to care for oneself that brought the Delphic maxim into operation' (2000g: p. 226).

There were many facets through which the ancient Greeks understood the notion of care of self and Foucault produces extensive descriptions of these in the volumes of the History of Sexuality, but one of the key general points identified is that for the ancient Greeks

sexual activity was perceived as natural (natural and indispensable) since it was through this activity that living creatures were able to reproduce, the species as a whole was able to escape extinction, and cities, families, names, and religions were able to endure far longer than individuals, who were destined to pass away (1985a: p. 48). 
Sexuality was, then, understood to be a natural phenomenon and, as such, was configured around a whole set of practices and norms to do with the nature of the community and the desire to contribute to life after one had died. The logic surrounding sexuality was not then based around prohibitions; it was orientated towards the 'question of right use' (1985a: p. 52):

Foods, wines, and relations with women and boys constituted analogous ethical material; they brought forces into play that were natural, but that always tended to be excessive; and they all raised the same question: how could one, how must one "make use" (chrēsthai) of this dynamics of pleasures, desires, and acts? (1985a: pp. 51-52)

Importantly, the notion of chrēsis aphrodisiōn, or the right use of pleasures, had two senses: First, it denoted a period of time of the year or life where it was considered good to engage in sexual activity. Second, it referred to the way 'in which an individual managed his sexual activity, his way of conducting himself in such matters, the regimen he allowed himself or imposed on himself, the conditions in which he accomplished sexual acts, the share he allotted them in his life' (1985a: p. 53). We might call this second sense, an individual's style of sexual activity.

What is important about this second sense is that it is not based on an a priori binding to a fixed norm or positive law: 'It is not a question of what was permitted or forbidden among the desires that one felt or the acts that one committed, but of prudence, reflection, and calculation in the way one distributed and controlled his acts' (1985a: pp. 53-54). It was obviously necessary to respect 'the laws and customs of the land, to keep from offending the gods, and to heed the will to nature' (1985a: p. 54), but individual practices were not determined a priori by laws or even 'a clearly defined code' (1985a: p. 54). 'It was more a question of a variable adjustment in which one had to take different factors into account: the element of want and natural necessity; that of opportuneness, which was temporal and circumstantial; that of the status of the individual himself' (1985a: p. 54).

Far from being defined by rigid, universal (positive) laws pre-determining and dictating individual sexual behaviours, there was a flexibility and specificity to sexual activity that had to be continually negotiated to be 'adapted to suit the user and his personal status' (1985a: p. 59). This did not mean that there were no laws, but the way in which they were adhered to was a "techne or "practice," a savoir-faire that by taking general principles into account would guide action in its time, according to its context, and in view of its ends' (1985a: p. 62). As a consequence, the individual did not turn himself into an ethical subject by following universal principles or universalising the principles that informed his action. ' $[\mathrm{O}] \mathrm{n}$ the contrary, he did so by means of an attitude and a quest that individualized his action, modulated it, and perhaps even gave him a special brilliance by virtue of the rational and deliberate structure his action manifested' (1985a: p. 62). The notion that the ethical subject is defined by a specific attitude and engaged in an on-going personal quest to create his own ethical practices is a very particular form of sexual practice. To highlight its uniqueness, Foucault compares it to the Christian approach to describing and prescribing sexual practices. 
Foucault rejects the notion of a fundamental rupture between the ancient Greeks and Christianity. There are similarities between the two that created a bridge between them, although these are masked by the fact that the component pieces of the discourse are not only configured differently but are also orientated towards different ends (1985a: pp. 14-15). So, for example, Foucault notes that 'Christian asceticism and ancient philosophy are placed under the same sign: that of the care of the self. The obligation to know oneself is one of the central elements of Christian asceticism' (1985a: p. 227). However, the Christian notion of care for self entails different practices and attains an alternative signification than it does for the ancient Greeks. The Christian model is based on a particular metaphysics wherein 'the self is a part of that reality that must be renounced in order to gain access to another level of reality' (1985a: p. 238). Whereas the ancient Greeks saw sexuality as a natural act necessary for procreation and the continuation of the species, its Platonic heritage brought Christianity to hold that the natural world is that to be escaped from to obtain the purity of the transcendent realm of the divine. All bodily pleasures were to be renounced, which, in turn, meant that the Greek care for self "was readily denounced as a form of self-love, a form of selfishness or self-interest in contradiction with the interest to be shown in other or the self-sacrifice required' (2000f: p. 284).

From the Christian perspective, therefore, the ways in which the Greeks went about caring for themselves by experimenting with different forms of self-expression based on the circumstances, need, and time were ultimately narcissistic and egoistical. Christians stressed the need to get away from the self by renouncing bodily pleasures to, in so doing, live a purer spiritual relation with God. This renunciation of the body was accompanied by the affirmation of the 'inner' life and, with it, specific practices of the self: 'forms of attention, concern, decipherment, verbalization, confession, self-accusation, struggle against temptation, renunciation, spiritual combat, and so on' (1985a: p. 63).

The Christian model of renunciation also created and depended upon a whole range of affirmative practices, including a network of institutions, such as the monasteries, where such practices could be closely controlled. In turn, confession of transgressions came to the fore to reveal and support the importance of power hierarchies wherein individuals were placed under the supervision of an institutional hierarchy that punished, supported, and moulded the individual based on predetermined rules of conduct.

These were completely absent from the Greek conception of care for the self which was "much more orientated towards practices of the self and the question of askessis than toward codifications of conducts and the strict definition of what is permitted and what is forbidden' (1985a: p. 30). Whereas the Christian sense of asceticism maintains that pleasure is a negative to be renounced, the Greek sense of 'ascesis is something else: it's the work that one performs on oneself in order to transform oneself or make the self appear, which, happily, one never attains' (2000b: p. 137). The key point that Foucault draws from this is that ' $[\mathrm{n}] \mathrm{o}$ technique, no professional skill can be acquired without exercise; neither can one learn the art of living, the tekhnē tou biou, without an askēsis which must be taken as a training of oneself by oneself' (2000h: p. 273). Both the Greek and Christian ethics of care for 
self contain this moment of self-discipline and training; indeed, it must be part of all ethics of the self because it is the process through which 'one attempts to develop and transform oneself, and to attain to a certain mode of being' (2000f: p. 282).

Different types of care of the self are possible because Foucault notes that they are constructed from and around different configurations of four aspects: First, there is 'the ethical substance [substance éthique]' (2000h: p. 263) that implicitly underpins any view of the self. For example, Foucault explains that 'from the Kantian point of view, intention is much more important than feelings [whereas] from the Christian point of view, it is desire ... [and] [f]or the Greeks, the ethical substance was acts linked to pleasure and desire in their unity' (2000h: p. 263). 'The second aspect is ... the mode of subjectivation [mode d'assujettissement], that is, the way in which people are invited or incited to recognise their moral obligations' (2000h: p. 264). This is tied to the social norms and power discourses and relations within which the subject exists which define acceptable ways of behaving, acting, and so on. In turn, this is linked to the question of how a particular ethical code substantiates itself, such as whether it appeals to emotion, natural law, reason, theology, or some alternative to ultimately ground its claims. The third aspect refers to the agency through which 'we can change ourselves in order to become ethical subjects' (2000h: p. 265). Amongst other things, it outlines how we moderate our actions and decide what we are to be, including how we are to create this. For Foucault, this is the moment of self-transformation through the regulation of one's own behaviour'asceticism in a very broad sense' (2000h: p. 265). The fourth aspect refers to the telos of the ethical subject: to what end is it directed. 'For example, shall we become pure, or immortal, or free, or masters of ourselves, and so on?' (2000h: p. 265). This is the normative aspect of the ethical system that sets the ethical norm that grounds the agent's asceticism.

By showing that the Greeks and Christians configured the respective aspects differently, Foucault highlights that each had different approaches to sexuality and, by extension, different ways of training the self. They were, in short, conditioned by different forms of spirituality, as Foucault understands the term and to which I will shortly return, with "moral conceptions in Greek and Greco-Roman antiquity [being] much more orientated toward practices of the self and the question of askêsis than toward codifications of conducts and the strict definition of what is permitted and what is forbidden' (1985a: p. 30). This disjunction interests Foucault and brings him to look to the ancient Greeks for a radically alternative ethics to the model of renunciation constitutive of Christianity and the instrumental rationality of modern ethics. The purpose however is not simply to re-affirm the Greek model. After all, their ethic was exclusionary, in that it was only enacted by a very small portion of the population (2000h: p. 254), and is clearly not suitable for the complexities of modern societies: 'you can't find the solution of a problem in the solution of another problem raised at another moment by other people' (2000h: p. 256). What it can do, however, is disrupt the certainty of modern ethical codes, showing that they are not the only ones available, and provide ideas to stimulate the ethical rethinking that occurs from that opening.

This is important because Foucault notes that we in the West have become used to thinking of our ethics, everyday life, economy, and politics as being intertwined 
in a delicate balance where to change one aspect is to risk ruin. He asks us to disentangle these relations by 'get[ting] rid of this idea of an analytical or necessary link between ethics and other social or economic or political structures' (2000h: p. 261). Through this disentanglement, there is an opening in terms of the options available to the self. From this, we are led to the question of how the ethical subject should act. Foucault takes inspiration from the Greek's emphasis on an aesthetics of the self to insist that it not be based on 'a codification of acts, nor towards a hermeneutics of the subject, but toward a stylization of attitudes and an aesthetics of existence' (2000h: p. 292). This allows him to point toward the following normative prescription: the self should be orientated by an openness to all practices.

\section{The Question of Sociality}

However, one of the most frequently cited objections to Foucault's position is that it is a purely individualistic account of ethical self-creation that lacks any consideration of social commitments or consideration for others. Richard Wolin, for example, argues that 'Foucault's standpoint favours either an attitude of narcissistic selfabsorption or one of outwardly directed, aggressive self-aggrandisement. In neither case is there a discernible trace of human solidarity, mutuality, or fellow-feeling' (1986: p. 85). Peter Dews complains that 'it is difficult to see how in contemporary society any such turn towards an aesthetics of existence could be anything other than a re-enforcement of social tendencies towards atomisation' (1989: p. 40). Similarly, Pierre Hadot suggests that by affirming an aesthetics of the self, 'Foucault might have been advancing a cultivation of the self which was too purely aesthetic - that is to say, I fear, a new form of dandyism, a late twentieth-century version' (1992: p. 230), while Ranier Rochlitz (1992: p. 253) protests about the lack of universality in Foucault's account, and Alexandros Kioupkiolis (2012: p. 392) objects to his failure to understand and account for the cultural dimension of social existence.

This line of critique fails, however, to properly understand the socially constituted and embedded nature of the Foucauldian self. Not only does Foucault's account of power relations reject the notion of the foundational subject to show that the self is constituted by its interactions with others, but in the 1983 interview 'On the Genealogy of Ethics,' he specifically responds to the question of whether his ethics is simply one of self-absorption by distancing himself from 'the Californian cult of the self [in which] one is supposed to discover one's true self, to separate it from that which might obscure or alienate it' (2000h: p. 271). There simply is no authentic, true self to be found or worked on; rather, there is a self to be invented and created, which is a social act.

The sociality inherent in his understanding of ethics is developed through his analysis of what it meant to freely care for oneself in ancient Greece. This was not an individual act, but a fundamentally socio-political one, not only because to have the status of 'free' was to be opposed to slavery and 'a slave has no ethics' (2000f: p. 286), but also because a free self was intimately tied to practices of moderation and acceptability. To be free required that "with respect to oneself one establishe[d] a certain relationship of domination, of mastery, which was called arkhe, or power, 
command' (2000f: pp. 286-287). That the free self was in command of himself meant that he was not simply orientated to the satisfaction of his own desires, which would make him in thrall to them. Freedom for the ancient Greeks was not understood in terms of atomization and independence, but in terms of the individual's appropriate activities within his social world: 'The freedom that needed establishing and preserving was that of the citizens of a collectivity of course, but it was also, for each of them, a certain form of relationship of the individual with himself' (1985a: p. 79).

While the organisation of the city, its laws, education, and the comportment of its leaders were crucial in creating and sustaining the 'correct' individual behaviours, 'the freedom of individuals, understood as the mastery they were capable of exercising over themselves, was indispensable to the entire [S]tate' (1985a: p. 79). The social embeddedness of the individual and the symbiotic relationship between the State and individual points to the notion that individual freedom required a certain form of self-control and moderation (1985a: p. 61). It was then linked to 'knowledge of a certain number of rules of acceptable conduct' (2000f: p. 285) and so was a 'true social practice' (1985b: p. 51). However, it is important to remember that these rules do 'not exist ... in a timeless heaven, with people who would be like astrologers of the good, able to determine the favourable conjunction of the stars. The good is defined, practiced, invented ... [T] his requires the work not just of some, [but] a collective work (2016c: p. 138). Although the specifics of how the collective works to structure an individual's self-creation are under-theorized, this is necessarily so because it is a wholly context-specific process. It cannot therefore be predetermined or placed under a single foreclosing schema. Foucault's basic point however is that self-creation should never be thought of as a matter of individuals autonomously choosing themselves regardless of others; it is an inherently social process that occurs through and in negotiation with the actions of others and the changing matrix of social norms.

\section{Re-thinking Normativity}

Foucault's affirmation of an ethics of the self is not then based on a model of selfabsorption or asocial self-affirmation; it is a socially embedded practice that, as such, depends on individuals expressing themselves spontaneously in negotiation with and through the constantly changing parameters of their continuously altering social context. It is here that the question of the normativity inherent in Foucault's later thinking comes to the fore. As noted, there is contention in the literature surrounding this issue, with the traditionally dominant view being that he does not offer a normative account, or if he does it is not, strictly speaking, permitted by his account. Proponents of this view usually do not mention these statements, but they might have bolstered their position by pointing out that Foucault repeatedly rejects the notion that his task is to prescribe how individuals should act: 'I am wary of imposing my own views, or of setting down a plan, or program' (2000c: p. 154); 'I never behave like a prophet-my books don't tell people what to do' (2000a: p. 
131); 'there is always something ludicrous in philosophical discourse when it tries, from the outside, to dictate to others, to tell them where their truth is and how to find it, or when it works up a case against them in the language of naive positivity' (1985a: p. 9), and

I am not a prophet! I am not a programmer, I don't have to tell [people] what they have to do, I don't have to tell them: “This is good for you; this isn't good for you." I try to analyze a situation in all its complexity, with the function, [for] this task of analysis, of allowing at once refusal, curiosity, and invention. That's it ... I don't have to tell people: "This is good for you" (2016c: p. 137).

Whereas these statements appear to support the charge that Foucault offers no normative program, the problem with such a critique and the conclusion it generates-namely, that there is no (justified) normativity in Foucault's thinking-is that it is based on a particularly reductionist (not to mention, on Foucault's terms, Christian) understanding of normativity that thinks of it in terms of the prescription of transcendent, universal rules to determine and judge action.

Certainly, Foucault explicitly rejects any appeal to universal laws-'I don't accept either the notion of mastery or the universality of law' (2002: p. 294) —and the notion and legitimacy of a 'founding act of reason' (2000j: p. 442) that could be used to establish a norm to program and direct future action. Doing so would produce a static model to be followed; one that would, in so doing, reduce the contingencies of concrete reality to a universal abstraction (2000h: p. 256) ${ }^{6}$ However, that Foucault rejects the existence of transcendent, universal rules to guide future action does not mean that he rejects all forms of normativity. One of the key tasks that I understand that Foucault undertakes in his later works is to see if it is possible to develop a form of normativity based on the study of immanent historical practices. As such, he rejects the notion that normativity must be understood in terms of the establishment of a priori rules, but affirms an alternative notion of normativity, which I will call 'normativity as an open practical principle.'

This depends, as previously outlined, on Colin Koopman's distinction between normative 'orientations' (2013: p. 189), which describe the 'structural background, or formal conditions... of possibility of ethical response in the present' (2013: p. 189), and normative 'commitments (or contents, theses, positions, strategies, techniques, equipment, rules, and concepts) offered by an ethics [which] specify the conditioned practical matters of an ethics thus oriented' (2013: p. 189). A normative

\footnotetext{
6 This is not, to say that Foucault does not appeal to formal rules; his later affirmation of human rights, for example, continues to make use of them. However, this appeal is, as Ben Golder notes, 'as potentially useful, tactical instruments in political struggle, as political tools immanent and not exterior to the field of political combat' (2015: p. 6). Besides talking of the political, rather than the ethical, efficacy of appealing to formal rules/concepts, the fundamental point is to avoid falling into an either/or logic of affirming formal rules or contingent practices; rather, Foucault affirms both, but emphasizes that the former must be thought in terms of tactical tools of the latter rather than in terms of universal, ahistorical foundations. After all, what gives content to a right depends upon the way it is practiced. This lack of a priori universal rules to dictate (or constrain) action is not, for Foucault, politically useless nor does it make action directionless and arbitrary. As he explains, 'being without a program can be very useful and very original and creative' (2000d: p. 172).
} 
orientation points to the (empty) 'background,' or 'pre-reflective' stance that structures ethical commitments and action; it orientates action without providing specific determinations as to the appropriate types of actions to be adopted. Such content is provided by the individual's normative commitments that determine the specific actions necessary to act ethically and to fulfil one's orientation. Whereas there is a tendency to pitch prescriptive normativity at the level of commitments, Foucault's innovation is to argue that normativity should be pitched at the level of orientation. Instead of being rule-based, he insists the orientation is defined by a particular open-ended, indeterminate focus that individuals should adopt — this is why his later thinking is prescriptively normative and, indeed, universalist; he affirms one ethical orientation for all individuals-without prescribing the commitments that must be engaged with to realize or actualize that orientation. This is left up to individuals to determine through their particular practical, context-based experimentation.

This is supported by the distinction that Foucault makes between 'morality' and 'ethics.' Morality, for Foucault, describes 'a set of values and rules of action that are recommended to individuals through the intermediary of various prescriptive agencies such as the family (in one of its roles), educational institutions, churches, and so on' (1985a: p. 25). These formal rules can be made explicit in codified form or they can be 'transmitted in a diffuse manner' (1985a: p. 25). In any case, they come from outside the individual and outline in advance what is expected. However, Foucault warns that although there are moral rules recommended to the individual, these do not determine his behaviour nor are they as homogeneous as they claim to be. The individual contributes to the realization of the code through his practical actions. These are not defined by adherence to a formal rule, but are created by the individual within his specific context. How individuals actually relate to those moral codes and rules delineates their ethics, which refers 'to the real behaviour of individuals in relation to the rules and values that are recommended to them' (1985a: p. 25). It delineates the ways in which 'individuals are urged to constitute themselves as subjects of moral conduct' (1985a: p. 29). These are not premised on adherence to formal a priori rules that, if followed, ensure their ethical status. Ethics is practiced, with these practices being guided by and spontaneously realizing an individual's normative orientation.

For this reason, Foucault's notion of ethical normativity is also intimately tied to and dependent upon his understanding of spirituality. Various commentators (Carette, 2013; May, 2000; Rabinow, 2009; Westerink, 2019; White, 2014) have recently engaged with this aspect of Foucault's later works and my purpose is not to engage with their analyses or, indeed, all aspects of Foucault's thinking on this issue; an undertaking that would require substantially more space than can be devoted here. Rather, I will aim to bring out aspects of his thinking on this topic to demonstrate that his account of ethical normativity is tied to and depends upon a particular form and understanding of spirituality. To do so, and while Jeremy Carette is surely correct to remind us that 'Foucault did not have one reading of "spirituality"' (2013: p. 54), I will focus on Foucault's comments on the topic in his 1981-1982 lecture course at the Collège de France, translated as The Hermeneutics of the Self (Foucault, 2005) because it is here that he provides the most schematic account of what he means by 'spirituality.' 
The discussion takes place through an outline of the relationship between philosophy and thought as these are orientated to questions of truth, a constellation from which Foucault tentatively claims that:

I think we could call "spirituality" the search, practice, and experience through which the subject carries out the necessary transformations on himself in order to have access to the truth. We will call "spirituality" then the set of these researches, practices, and experiences, which may be purifications, ascetic exercises, renunciations, conversions of looking, modifications of existence etc., which are, not for knowledge but for the subject, for the subject's very being, the price to be paid for access to the truth' (Foucault, 2005: p. 15)

He goes on to explain that 'spirituality, as it appears in the West at least, has three characteristics' (2005: p. 15). First, truth is not simply given to the subject, but, in a sense, must be won through a particular struggle. '[F]for the subject to have right of access to truth he must be changed, transformed, shifted, and become, to some extent and up to a certain point, other than himself' (2005: p. 15). For this reason, second, 'there can be no truth without a conversion or a transformation of the subject' (2005: p. 15), with the conversion taking place through two principle forms: (1) love, wherein 'a movement [occurs] that removes the subject from his current status and condition (either an ascending movement of the subject himself, or else a movement by which the truth comes to him and enlightens him)' (2005: pp. 15-16), or (2) askessis, in which there 'is a work of the self on the self, an elaboration of the self by the self, a progressive transformation of the self by the self for which one takes responsibility in a long labor of ascesis (askēsis)' (2005: p. 16). Whereas 'spirituality as love' involves an action that, in a sense, is done to the subject and, indeed, appears to be tied to Christianity, 'spirituality as askēsis' is a form of practical transformative activity that the subject does to itself and is tied to the ancient Greeks, for whom philosophy and spirituality were intimately connected; that is, the search for truth was a practical activity requiring individual transformation. For this reason, Foucault subsequently concludes, in the 1984 essay 'The Ethics of the Concern for Self as a Practice of Freedom,' that 'By spirituality I mean ... the subject's attainment of a certain mode of being and the transformation that the subject must carry out on itself to attain this mode of being' (2000f: p. 294).

Finally, Foucault notes that, although spirituality is tied to the search for truth, 'truth' here is not based on a model of epistemic representation, wherein the subject attempts to correctly re-present an already existing world and truth-claims are judged valid based on the accuracy of that re-presentation. Rather, there exists a sort of dialectical relation between the subject, truth, and spirituality wherein once the subject gains access to truth, that experience produces effects that 'rebound (" $d e$ retour") ... on the subject' (2005: p. 16) to transform him. As such, spirituality (as askēsis) does not see 'truth' as a reward that is given to the subject for his endeavours, but insists that the (search for the) truth impacts on the very being of the subject: 'The truth enlightens the subject; the truth gives beatitude to the subject, the truth gives the subject tranquillity of the soul. In short, in the truth and in access to the truth, there is something that fulfils the subject himself, which fulfils or transfigures his very being' (2005: p. 16). This ties into and depends upon Foucault's claim 
that 'truth' is not an ahistoric entity, but a historical product that is always intimately tied up with social practices (2000f: p. 296). Thus, the subject that undergoes the spiritually transformative conversion inherent in askessis does not attain 'the truth' per se, but establishes a mode of being - he lives truthfully - that is conditioned by a particular spirit that continuously searches for and to an extent creates the truth through the (social) practices he adopts.

Although there is obviously more that could be said about this-with Foucault's final two seminars on the topic of parrhessia, or truth-telling through frank speech, being particularly pertinent (see Foucault, 2010b, 2011)_-if we put the pieces of this schematic outline together we see that Foucault is pointing to a particular form of spirituality that refers to a practical activity of (continuous) self-transformation. So, rather than existing apart from the truth which is given to the subject from an external source or as a reward for a particular journey, individuals exist in a symbiotic relation to 'truth' which must be realized through an on-going process of practical (spiritual) askessis. This re-enforces my claim that, instead of affirming a Christianinspired account premised on adherence to a priori (ethical) rules (sanctioned by the divine) that are to be followed regardless of the circumstance, Foucault's affirmation of spirituality as askēsis maintains that ethics cannot be prescribed in advance but requires that individuals search for the truth through the practices adopted; a process that requires experimentation. Therefore, as Edward McGushin (2020: p. 473) explains, Foucault's notion of spirituality is not an epistemological or theological concept, but an inherently ethical and political one: the former because it involves the subject transforming himself and the latter because, as I previously pointed out, individual action takes place in and through relations with others. ${ }^{7}$

Undertaking a genealogy of the subject through the sexual practices of the ancient Greeks and early Christians brings Foucault to argue that, in contrast to the latter, the ancient Greeks did not simply conflate morality and ethics or privilege the former, but held the two apart to affirm the importance of the latter. While society affirmed a particular moral norm to prescribe how individuals should act, which in turn shaped (without determining) the individual's orientation, what this meant and how it was practiced depended upon how it was taken up and re-affirmed by individuals in their particular social context. Furthermore, instead of insisting that each individual model his activities on predetermined, universal rules/activities, the Greeks left it up to each individual to express himself in each moment. As a consequence, the Greeks held that the ethical worth of each individual was revealed, not through his adherence to a predetermined rule, but through his practices:

A person's èthos was evident in his clothing, appearance, gait, in the calm with which he responded to every event, and so on. For the Greeks, this was the concrete form of freedom; this was the way they problematized their freedom. A man possessed of a splendid $\bar{e} t h o s$, who could be admired and put forward

\footnotetext{
7 Infamously, Foucault (1988) expands on the political dimension of spirituality in his controversial defense of the Iranian Revolution.
} 
as an example, was someone who practiced freedom in a certain way (2000f: p. 286).

That each individual could and would practice it differently meant that the means for self-expression and self-creation were heterogeneous; in fact, they were wide open.

However, while this identifies that the manner or practices that bring individuals to operationalize their orientating principle are heterogeneous, the status of the orientating principle itself needs to be clarified. Those, such as Koopman or Golob, who insist that Foucault's schema is orientated towards the notion of universizability implicitly claim that there is a single aim underpinning each individual's ethical practice: individuals adopt different practices to try to gradually work out which norm is universizable. On this reading, the heterogeneity at the level of practice is and should be orientated towards the discovery of a single norm applicable to all individuals and contexts. Although it seems that both authors want this to be revisable, they maintain that Foucault's affirmation of different practices is underpinned by the desire to identify a homogeneous orientating norm; one that all individuals can and should adopt. The means to identify this are on-going, practice-based, and heterogeneous, but such practices are underpinned by a transcendent aim that tries to discover $a$ norm to be adopted.

Ultimately, however, I think that there are two problems with this understanding. First, Foucault does not hold that an individual's normative commitments, as revealed through his practices, shape his orientation, but that an individual's orientation is the framework that shapes his commitments and, by extension, practices. Of course, I am not claiming that this does not mean that there is no feedback loop so that an individual's practices can lead him to change his orientation. However, second, I am uneasy about the claim, which I take to be implicit in Koopman's and Golob's position, that an individual's orientation is underpinned by some sort of transcendental or meta-contextual aim for a single orientating norm that would outline the sorts of practices valid for all contexts and individuals. Instead, I want to suggest that Foucault's analysis of the ancient Greeks points to a conception of ethics that is inherently open-ended at both the levels of normative orientation and normative commitments. Only this will break the confines of moral systems to ensure that the individual is genuinely free, open him up to new practices, and allow individuals to live the specifics of each context. As Foucault puts it:

The critical ontology of ourselves must be considered not, certainly, as a theory, a doctrine, nor even as a permanent body of knowledge that is accumulating; it must be conceived as an attitude, an ethos, a philosophical life in which the critique of what we are is at one and at same time the historical analysis of the limits imposed on us and an experiment with the possible of going beyond them [de leur franchissement possible] (2000i: p. 319).

Rather than foreclose each moment within an abstract predetermined transcendent rule or aim, Foucault insists that we learn to revel in the moment. As William Connelly explains, 'the goal is to modify an already contingent self-working within the narrow terms of craftsmanship available to an adult-so that you are better able 
to ward off the demand to conform transcendentally to what you are contingently' (1993: p. 373). Transcendent positions are disqualified by Foucault's claim that phenomena emanate from and are conditioned by ever-changing dynamics. No one practice, and by extension positive norm, is suitable for all circumstances and, as such, the self must continuously make itself anew in each moment. For this reason, Foucault insists that each individual should avoid all (positive) predeterminations regarding what is right/wrong. As such, Foucault does affirm a universal orientating principle, but it is an empty or negative one: each individual's ethical orientation should be open, which means that each should avoid foreclosing their commitments within a predefined (positive) moral/ethical schema. Only this will genuinely free individuals to express themselves in each moment, while also undermining any claim for a transcendent meta-position that would allow individuals to tell others how to act and so foreclose their actions (2016c: p. 137).

Foucault offers then and depends upon a normative position but it is, as he notes, in many respects a negative one that removes foreclosing structures, ends, and norms that predetermine the individual away from certain practices regardless of context (2016c: pp. 136-137). After all, what is unsuitable to one configuration may be suitable for another and vice versa. It is for this reason that Foucault explains that 'instead of deducing concrete phenomena from universals, or instead of starting with universals as an obligatory grid of intelligibility for certain concrete practices, I ... start with these concrete practices and, as it were, pass these universals through the grid of these practices' (2008: p. 3). Instead of appealing to, depending on, or searching for a singular, positive rule or norm to ground individual action, Foucault recognises and works from the contextual embeddedness of the subject to claim that it should be orientated to remaining open to experimenting with different practices and positions to the extent permitted by and expressed in conjunction with its particular social norms. No two responses will ever be the same, but each response reveals each individual's ethical style. ${ }^{8}$ Only this schema allows the subject to remain genuinely undetermined in each moment and, as such, able to respond practically to the particularities of each situation; action that is conditioned by and always takes place in and through the changing dynamics of its relationship to others.

\section{Concluding Remarks}

Foucault's later work on the self is therefore inherently normative, insofar as, contrary to a long-standing charge, it does offer a coherent account of how the self should act. However, I have also shown that the normativity at play is of a very

\footnotetext{
${ }^{8}$ It is for this reason that it is not possible to provide detailed concrete examples to illustrate Foucault's point; doing so would risk providing a transcendental blueprint for individual action that would foreclose such action within a universal model. As I have argued, the entire point of Foucault's normative ethics is to forego such a model so as to, in a sense, ask that individuals face up to the situation, determine how they are to act in that situation in order to transform themselves, and take responsibility for the consequences of such actions. Appealing to hypothetical examples cannot help us or the individual in this matter because each context will be completely different, as will each individual's reaction to it.
} 
particular and innovative kind that has been largely misunderstood by those commentators who have affirmed that he does offer a normative stance. To correct this, it is necessary to combine aspects of their respective positions, in combination with some insights that they overlook. From this, I have argued that Foucault compares and contrasts the ethical systems of the ancient Greeks and early Christianity to show that the absence of an absolute ground-as outlined by his account of power relations - not only undermines the claims of the latter but leads to the question of how individuals should act. In the absence of absolute universal foundations to ground and justify moral norms, the only option, so Foucault maintains, is to throw ourselves into contingency by being willing to constantly remake ourselves and our ethics based on the specifics of each situation. This requires that we remain genuinely open to every context; a difficult and on-going task, but one that Foucault claims is necessary for individuals to truly be free.

The key to understanding the normativity at play in this practice-based ethics is to distinguish between an individual's normative orientation and his normative commitments; the former describing the indeterminate attitude or style that guides the creation of the specific rules, norms, and values of the latter. Whereas prescriptive normativity is often pitched at the latter, insofar as it outlines specific determinations that foreclose how an individual should act regardless of context, Foucault's later work argues for the adoption of a particular orientation that undermines all such foreclosing to affirm an ethics of continuous practical openness. In other words, Foucault does affirm a prescriptive stance that identifies how we should act, but it is normative at the level of the general ethical orientation to be adopted to guide specific individual ethical action. This normative orientation is universal, insofar as it affirms a single principle to orientate all selves regardless of context, but, crucially, it is an empty and indeterminate guiding principle that requires that individuals remain open to the specifics of each situation. Only this prevents individuals from foreclosing their activities within predetermined schemas, ends, and values. Therefore, instead of an individual's commitments being pre-determinable or reducible to a universal end, the indeterminacy of the orientating principle, in combination with the specificity of each context, permits and even demands that individuals spontaneously create responses for each context. For this reason, Foucault maintains that the normative orientating principle is given content and, by extension, an individual's ethical commitments are revealed, from and through a spontaneous and on-going practical process of experimentation in response to the specifics of each (social) situation. Read in this way, Foucault's later engagements with the ethical systems of ancient Greece and early Christianity allow him to develop a particularly radical and innovative ethics of practical openness, clarify that this entails the affirmation of a universal but empty normative principle that orientates without determining individual ethical commitments, and demonstrates that this principle is given content through an on-going and inherently spontaneous process of individual practical experimentation that takes place through and in negotiation with a complex and ever-changing web of social norms and interactions. 
Funding Open Access funding provided thanks to the CRUE-CSIC agreement with Springer Nature.

Open Access This article is licensed under a Creative Commons Attribution 4.0 International License, which permits use, sharing, adaptation, distribution and reproduction in any medium or format, as long as you give appropriate credit to the original author(s) and the source, provide a link to the Creative Commons licence, and indicate if changes were made. The images or other third party material in this article are included in the article's Creative Commons licence, unless indicated otherwise in a credit line to the material. If material is not included in the article's Creative Commons licence and your intended use is not permitted by statutory regulation or exceeds the permitted use, you will need to obtain permission directly from the copyright holder. To view a copy of this licence, visit http://creativecommons.org/licen ses/by/4.0/.

\section{References}

Allen, A. (2008). The politics of ourselves: Power, autonomy, and gender in contemporary critical theory. Columbia University Press.

Allen, A. (2014). Normativity, power, and gender: Reply to critics. Critical Horizons, 15(1), 52-68.

Bevir, M. (1999). Foucault and critique: Deploying agency against autonomy. Political Theory, 27(1), 65-84.

Butler, J. (1999). Gender trouble: Feminism and the subversion of identity. Routledge.

Carette, J. (2013). Rupture and transformation: Foucault's concept of spirituality reconsidered. Foucault Studies, 15, 52-71.

Connelly, W. E. (1993). Beyond good and evil: The ethical sensibility of Michel Foucault. Political Theory, 21(3), 365-389.

Dews, P. (1989). The return of the subject in late Foucault. Radical Philosophy, 51(1), 37-41.

Erlenbusch-Anderson, V. (2018). Genealogies of terrorism: Revolution, state violence, empire. Columbia University Press.

Foucault, M. (1985a). A history of sexuality, volume 2: The use of pleasure (R. Hurley, Trans.). Penguin. Foucault, M. (1985b). A history of sexuality, volume 3: The care of the self (R. Hurley, Trans.). Penguin.

Foucault, M. (1988). Iran: The spirit of a world without spirit (A. Sheridan and Others, Trans.). In L. D. Kritzman (Ed.), Politics, philosophy, culture: Interviews and other writings, 1977-1984 (pp. 211224). Routledge.

Foucault, M. (2000a). An interview by Stephen Riggins. In P. Rabinow (Ed.), Ethics: Essential works of Foucault, 1954-1985 (vol. 1, pp. 121-133). Penguin.

Foucault, M. (2000b). Friendship as a way of life. In P. Rabinow (Ed.), Ethics: Essential works of Foucault, 1954-1985 (vol. 1, pp. 135-140). Penguin.

Foucault, M. (2000c). Sexual choice, sexual act. In P. Rabinow (Ed.), Ethics: Essential works of Foucault, 1954-1985 (vol. 1, pp. 141-156). Penguin.

Foucault, M. (2000d). Sex, power, and the politics of identity. In P. Rabinow (Ed.), Ethics: Essential works of Foucault, 1954-1985 (vol. 1, pp. 163-174). Penguin.

Foucault, M. (2000e). Sexuality and solitude. In P. Rabinow (Ed.), Ethics: Essential works of Foucault, 1954-1985 (vol. 1, pp. 175-184). Penguin.

Foucault, M. (2000f). The ethics of the concern for self as a practice of freedom (P. Aranov \& D. McGrawth, Trans.). In P. Rabinow (Ed.), Ethics: Essential works of Foucault, 1954-1985 (vol. 1, pp. 281-301). Penguin.

Foucault, M. (2000g). Technologies of the self. In P. Rabinow (Ed.), Ethics: essential Works of Foucault, 1954-1985 (vol. 1, pp. 223-252). Penguin.

Foucault, M. (2000h). On the genealogy of ethics: An overview of work in progress. In P. Rabinow (Ed.), Ethics: Essential works of Foucault, 1954-1985 (vol. 1, pp. 253-280). Penguin.

Foucault, M. (2000i). What is enlightenment? In P. Rabinow (Ed.), Ethics: Essential works of Foucault, 1954-1985 (vol. 1, pp. 303-320). Penguin.

Foucault, M. (2000j). Structuralism and poststructuralism. In J. D. Faubion (Ed.), Aesthetics: Essential works of Foucault 1954-1984 (vol. 2, pp. 433-458). Penguin. 
Foucault, M. (2002). Interview with Michel Foucault. In J. D. Faubion (Ed.), Power: Essential works of Foucault 1954-1984 (vol. 3, pp. 239-297). Penguin.

Foucault, M. (2005). Hermeneutics of the self: Lectures at the Collège de France, 1981-1982 (Davidson, A. I., Ed. \& Graham Burchell, Trans.). Picador.

Foucault, M. (2008). The birth of biopolitics: Lectures at the collège de France, 1978-1979 (Davidson, A. I., Ed. \& Graham Burchell, Trans.). Palgrave Macmillan.

Foucault, M. (2010a). The archaeology of knowledge (A. M. Sheridan Smith, Trans.). Vintage.

Foucault, M. (2010b). The government of self and others: Lectures at the Collège de France, 1982-1983 (Davidson, A. I., Ed. \& Graham Burchell, Trans.). Palgrave Macmillan.

Foucault, M. (2011). The courage of truth, the government of self and others II: Lectures at the Collége de France, 1983-1984 (Davidson, A. I., Ed. \& Graham Burchell, Trans.). Palgrave Macmillan.

Foucault, M. (2016a). Subjectivity and truth (G. Burchell, Trans.). In H.-P. Fruchard \& D. Lorenzini (Eds.), About the hermeneutics of the self: Lectures at Dartmouth college, 1980 (pp. 19-52). University of Chicago Press.

Foucault, M. (2016b). Discussion of "truth and subjectivity" (G. Burchell, Trans.). In H.-P. Fruchard \& D. Lorenzini (Eds.), About the hermeneutics of the self: Lectures at Dartmouth college, 1980 (pp. 93-126). University of Chicago Press.

Foucault, M. (2016c). Interview with Michel Foucault (G. Burchell, Trans.). In H.-P. Fruchard \& D. Lorenzini (Eds.), About the hermeneutics of the self: Lectures at Dartmouth College, 1980 (pp. 127138). University of Chicago Press.

Fraser, N. (1989a). Foucault on modern power: Empirical insights and normative confusions. In Unruly practices: Power, discourse, and gender in contemporary social theory (pp. 17-34). University of Minnesota Press.

Fraser, N. (1989b). Michel Foucault: A “Young Conservative?” In Unruly practices: Power, discourse, and gender in contemporary social theory (pp. 35-54). University of Minnesota Press.

Golder, B. (2015). Foucault and the politics of rights. Stanford University Press.

Golob, S. (2015). Subjectivity, reflection, and freedom in later Foucault. International Journal of Philosophical Studies, 23(5), 666-688.

Habermas, J. (1987). Some questions concerning the theory of power: Foucault again (F. Lawrence, Trans.). In The philosophical discourse of modernity: Twelve lectures (pp. 266-293). Polity.

Hadot, P. (1992). Reflections on the notion of "the cultivation of the self." In T. J. Armstrong (Ed. \& Trans.), Michel Foucault: Philosophy (pp. 225-232). Routledge.

Han-Pile, B. (2016). Foucault, normativity, and critique, as a practice of the self. Continental Philosophy Review, 49(1), 85-101.

Kelley, M. G. E. (2018). For Foucault: Against normative political theory. State University of New York Press.

Kioupkiolis, A. (2012). The agonistic turn of critical reason: Critique and freedom in Foucault and Castoriadis. European Journal of Social Theory, 15(3), 385-402.

Koopman, C. (2013). Genealogy as critique: Foucault and the problems of modernity. Indiana University Press.

McGushin, E. (2020). Spirituality. In L. Lawler \& J. Nale (Eds.), The Cambridge Foucault Lexicon (pp. 472-476). Cambridge University Press.

McNay, L. (1992). Foucault and feminism: Power, gender, and agency. Polity.

May, T. (2000). Philosophy as a spiritual exercise in Foucault and Deleuze. Angelaki: Journal of the Theoretical Humanities, 5(2), 223-229.

Patton, P. (2016). Government, rights and legitimacy: Foucault and liberal political normativity. European Journal of Political Theory, 15(2), 223-229.

Rabinow, P. (2009). Foucault's untimely struggle: Toward a form of spirituality. Theory, Culture, and Society, 26(6), 25-44.

Rae, G. (2020). Poststructuralist agency: The subject in twentieth-century theory. Edinburgh University Press.

Rochlitz, R. (1992). The aesthetics of existence: Post-conventional morality and the theory of power in Michel Foucault. In T. J. Armstrong (Ed. \& Trans.), Michel Foucault: Philosophy (pp. 233-247). Routledge.

Rozmarin, M. (2005). Power, freedom, and individuality: Foucault and sexual difference. Human Studies, 28(1), 1-14. 
Taylor, C. (1985). Foucault on freedom and truth. In Philosophical papers 2: Philosophy and the human sciences (pp. 152-184). Cambridge University Press.

Westerink, H. (2019). Thinking spirituality differently: Michel Foucault on spiritual self-practices, counter-conducts, and power-knowledge constellations. Religions, 10(2), Article 81.

White, R. (2014). Foucault on the care of the self as an ethical project and a spiritual goal. Human Studies, 37(4), 489-504.

Wolin, R. (1986). Foucault's aesthetic decisionism. Telos, 67(Spring), 71-86.

Publisher's Note Springer Nature remains neutral with regard to jurisdictional claims in published maps and institutional affiliations. 